\title{
CLIMATE ESTIMATES FOR EASTERN AMAZON WITH OLAM MODEL
}

\section{RENATO RAMOS DA SILVA ${ }^{1}$,MARIA ISABEL VITORINO², PAULO KUHN ${ }^{3}$, DANIELA DOS SANTOS ANANIAS ${ }^{2}$}

\author{
${ }^{1}$ Universidade Federal de Santa Catarina, Centro de Ciências Físicas e Matemáticas, Departamento de Física, \\ Florianópolis, SC, Brasil \\ ${ }^{2}$ Universidade Federal do Pará, Departamento de Meteorologia, Belém, PA, Brasil \\ ${ }^{3}$ Universidade Federal do Amazonas, Faculdade de Ciências Agrárias, Manaus, AM, Brasil
}

renato.ramos@ufsc.br, vitorino@ufpa.br,paulokuhn.1@gmail.com,dany_ananias@yahoo.com.br

Received September 2013 - Accepted January 2014

\begin{abstract}
The OLAM model has as its characteristics the advantage to represent simultaneously the regional and global meteorological phenomena using a refining grid scheme. During REMAM project OLAM was applied for a few case studies with the goal to evaluate its performance to estimate the regional climate for the eastern Amazon during periods of El Niño and La Niña. Case studies were performed for the rainy periods of the years 2010 and 2011 that were driven by distinct oceanic conditions. Initially, the model results were compared with local observations. The results demonstrated that OLAM was able to represent well the major precipitating regions, the diurnal temperature cycle evolution, and the wind dynamics. After that, analysis of the results demonstrated that if we provide good initial conditions and a good representation of the sea surface temperature evolution, OLAM is able to forecast with two or three months in advance if a rainy season would be wet or dry.

Keyword: Climate prediction, OLAM, precipitation, eastern Amazon.

\section{RESUMO: ESTIMAVAS CLIMÁTICAS PARA O LESTE DE AMAZÔNIA COM O MODELO OLAM}

O modelo OLAM tem como característica a vantagem de representar simultaneamente os fenômenos de escala global e regional através de um esquema de refinamento de grades. Durante o projeto REMAM o modelo foi aplicado para alguns estudos de caso com objetivo de avaliar o desempenho do modelo na estimativa do clima da região leste da Amazônia em períodos de El Niño e La Niña. Estudos de caso foram feitos para os períodos chuvosos dos anos 2010 e 2011 que apresentaram condições oceânicas distintas. Inicialmente, os resultados do modelo foram comparados com dados observados da região de estudo. Os resultados mostraram que o modelo consegue representar bem os principais centros convectivos da região e adjacências, da evolução local do ciclo diurno de temperatura, e da dinâmica dos ventos. Posteriormente, a análise dos resultados mostrou que, se tivermos bons dados de condição inicial e boa representação da evolução das condições de temperatura da superfície do mar, o modelo consegue prever com antecedência de dois e três meses se uma estação chuvosa será mais seca ou úmida.
\end{abstract}

Palavras-chave: Previsão climática, OLAM, precipitação, leste da Amazônia. 


\section{INTRODUCTION}

Regional climate prediction for the Amazon region is of great importance. This region is characterized by high downward solar radiation and boundary layer moisture producing strong turbulent fluxes and convection. Remote effects are constantly modifying the tropical weather. For instance, the seasonal migration of the Inter-tropical convergence zone (ITCZ) sets important regional climate variability (Uvo et al., 1998, Robertson et al. 2000). The Atlantic oceanic conditions also have an important effect on the climate variability near the region (Moura and Shukla, 1981; Nobre and Shukla, 1996). In addition, the Madden-Julian Oscillation (MJO; Madden and Julian, 1972) can have important effects on the local precipitation (Souza and Ambrizi, 2006). Further, the climate variability such as the El Niño conditions can affect the region via atmospheric teleconections. In general, El Niño regimes are associated with lower precipitation over the eastern Amazon region (Grimm, 2003; Marengo, 2004).

The Amazon region is also affected by large scale and remote events, but, at the same time its strong local convection can affect the climate in other regions. For instance, perturbations in the Amazon's convection can produce Kelvin waves that reaches Africa (Wang and Fu, 2007; Kiladis et al., 2009). Also, perturbations on local convection caused by possible large scale deforestation can propagate effects on several other regions (Werth and Avissar, 2002). Therefore, there is a two way interaction between the Amazon and the large scale climate system conditions.

Furthermore, the surface heterogeneity has a major impact on the local atmospheric circulations and regional rainfall distribution. The eastern Amazon has a complex interface with the Atlantic Ocean, is crossed by large rivers and is covered with heterogeneous vegetation. The surface heterogeneity can produce horizontal temperature and pressure gradients which can develop local atmospheric circulations affecting the convection and precipitation. Examples of these circulations are the river breeze (Silva Dias et al., 2004), the cloud streets (Ramos da Silva et al., 2011) and the sea breeze influence on the squall lines formation (Cohen et al., 1995). Predicting these mesoscale phenomena requires a high resolution model.

A series of regional modeling for the Amazon was conducted recently (Roads et al., 2003; Chou et al., 2005; Souza et al., 2009; Alves et al., 2012; da Rocha et al., 2012; Ferreira et al., 2012). However, these studies were conducted with limited-area models that depend of atmospheric boundary conditions from coarse global models. Therefore, these models do not have a two-way interaction between the Amazon region and the large scale environmental conditions. Furthermore, their results still are not realistic if compared with the observations (Roads et al., 2003).

Then, to fully represent and predict the regional climate of this region, a model needs to have high spatial resolution to be able to represent the local effects of the land heterogeneity and to account for the influence of remote systems, simultaneously.

The new Ocean-Land-Atmosphere Model (OLAM) has this capability. This model can represent the global atmospheric circulation using a coarser icosaedrical grid and simultaneously have an improved regional resolution through a grid refinement (Walko and Avissar, 2008a, b; Ramos da Silva et al., 2009).

During the project REMAM (Monitoramento e Pesquisa de Fenômenos Meteorológicos Extremos na Amazônia) a series of modeling experiments were performed to evaluate the regional climate modeling for the eastern Amazon based on OLAM.

Here, we present the results of the case studies through a model evaluation and its capability for the regional climate precipitation estimation.

\section{METHODOLOGY}

\subsection{Region of study}

The eastern Amazon region is located near the equator at the northeast of the South America (Figure 1). The Amazon River crosses the region and reaches the Atlantic Ocean at the east of the domain. The major land cover type is forest, but urbanization and deforestation is modifying the landscape of the region. Climatological data shows that the region is dominated by the easterly trade winds that transport moist air from the Atlantic into the continental areas. The ocean conditions on the west Pacific and tropical Atlantic has an important influence on the local climate regime (Nobre and Shukla, 1996; Grim, 2003; Marengo, 2004).

\subsection{OLAM model}

The OLAM model is an evolution of the mesoscale Regional Atmospheric Modeling System (RAMS, Cotton et al., 2003) with improves in several aspects such as with the possibility of a global grid that uses an icosahedral structure (Figure 1). The dynamical core for the grid structure has a triangular grid type that fits the spherical domain. Higher spatial resolution can be achieved using a grid refinement approach. The prognostic equations are solved using the finite volume technique that maintains the conservation of mass, momentum and energy (Walko and Avissar, 2008a,b).

The major physical parametrizations adopted by OLAM are the same of the Regional Atmospheric Modeling System 


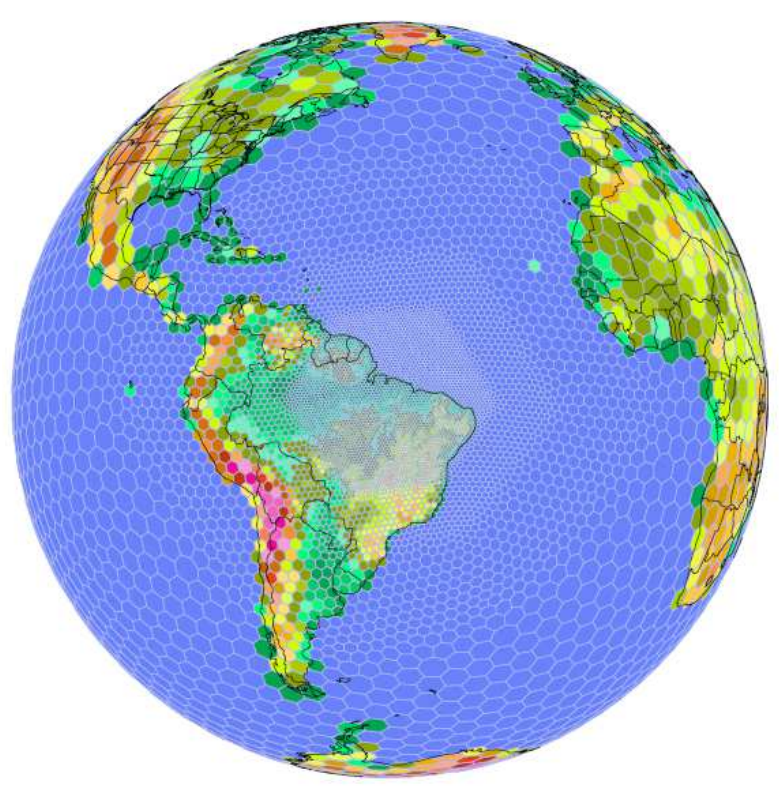

Figure 1 - OLAM model grid design for eastern Amazon.

(RAMS) including the land-vegetation interaction (Walko et al., 2000a), the cloud microphysics (Meyers et al., 1997; Walko et al., 1995, Walko et al., 2000b), the radiation transfer (Chen and Cotton, 1983; Harrington and Olson, 2001) and cumulus parametrization (Kain and Fritsch, 1990; Grell and Dévény, 2002). The RAMS mesoscale model was used in several applications for the South America studies, e.g. on the deforestation impacts (Gandu et al., 2004; Ramos da Silva and Avissar, 2006; Ramos da Silva et al., 2008); lightning formation (Gonçalves et al., 2012), convection transport (Freitas et al., 2000) and weather forecasting (Freitas et al., 2005; Ramos da Silva et al., 2007; Longo et al., 2013). Therefore, the physical parameterizations have been very well tested on several different systems for the South America region. However, RAMS is a limited area model. Because of that, it requires a nudging on its atmospheric boundaries by large scale data.

Recent studies with OLAM for the South America demonstrated that the model is able to represent the major regional climatic observed features of this region. The model was able to represent the regional climate and the predominant weather systems (Ramos da Silva et al., 2008; Medivgy et al. 2008, 2011, 2012).

\subsection{Numerical experiment design}

In this study, the OLAM model was set with a global grid having a refined spatial resolution for the eastern Amazon (Figure 1). The global coarser grid was set having about $250 \mathrm{~km}$ of grid spacing. To improve local resolution, a grid refinement was set with the innermost region having grid cells spaced on the order of $125 \mathrm{~km}, 64 \mathrm{~km}$, and $32 \mathrm{~km}$, respectively. The innermost domain having the highest grid resolution (i.e. 32 $\mathrm{km}$ ) was centered at the eastern Amazon (Figure 1).

The atmospheric initial conditions for winds, air temperature, geopotential height and air moisture were obtained from the NCEP/NCAR (National Centers for Environment Prediction/National Center for Atmospheric Research) reanalysis project (Kanamitsu et al., 2002). Since OLAM is a global model, nudging was not necessary. . Initial conditions for soil moisture and soil temperature were also obtained from NCEP/NCAR data. Weekly sea surface temperature (SST) was obtained from NOAA (National Oceanic and Atmospheric Administration) as described by Reynolds et al. (2002) and was updated during the model integration. The model surface boundary conditions of topography, soil texture, and vegetation types, were set using a global dataset.

To better evaluate the model performance and predictability, two periods were simulated comprehending the rainy seasons of the years 2010 and 2011. These two periods were chosen because they were driven by two different oceanic conditions (Figure 2). During the outset of the year of 2010 the tropical east Pacific was anomalously warmer characterizing an El Niño regime, while during the outset of the year of 2011 the SST at this region was anomalously cooler characterizing a La Niña regime (Figure 2). At the tropical north Atlantic, the SST was warmer than the climatology affecting the position of the ITCZ and the transport of moisture into the north coast of South America.

The accumulated precipitation data for January-February extracted from the Global Precipitation Climatology Project (GPCP), for the eastern Amazon region showed that during El Niño conditions (i.e. year of 2010) the region was drier than during the La Niña period (2011). During the La Niña of 2011 the accumulated precipitation was about $80 \%$ higher as compared with the same period of 2010 (Figure 3). The major difference between these two periods was that the ITCZ positioned at north of its mean position in early 2010 and south of that in early 2011. One consequence was a weaker transport of moisture in the north coast during early 2010 and the opposite during 2011 (Climanalise, 2010, 2011). Based on these observations, a major question we intend to check is if OLAM model would be able to predict those regimes if a proper initial atmospheric conditios and SST boundary condition would be provided.

Precipitation data obtained from TRMM satellite estimates were used to evaluate the model results. This data was used instead the GPCP data because the satellite covers both, the continental and oceanic regions. Also, to evaluate the results for atmospheric temperature and winds data were extracted from the new Modern Era Retrospective-Analysis for Research and 

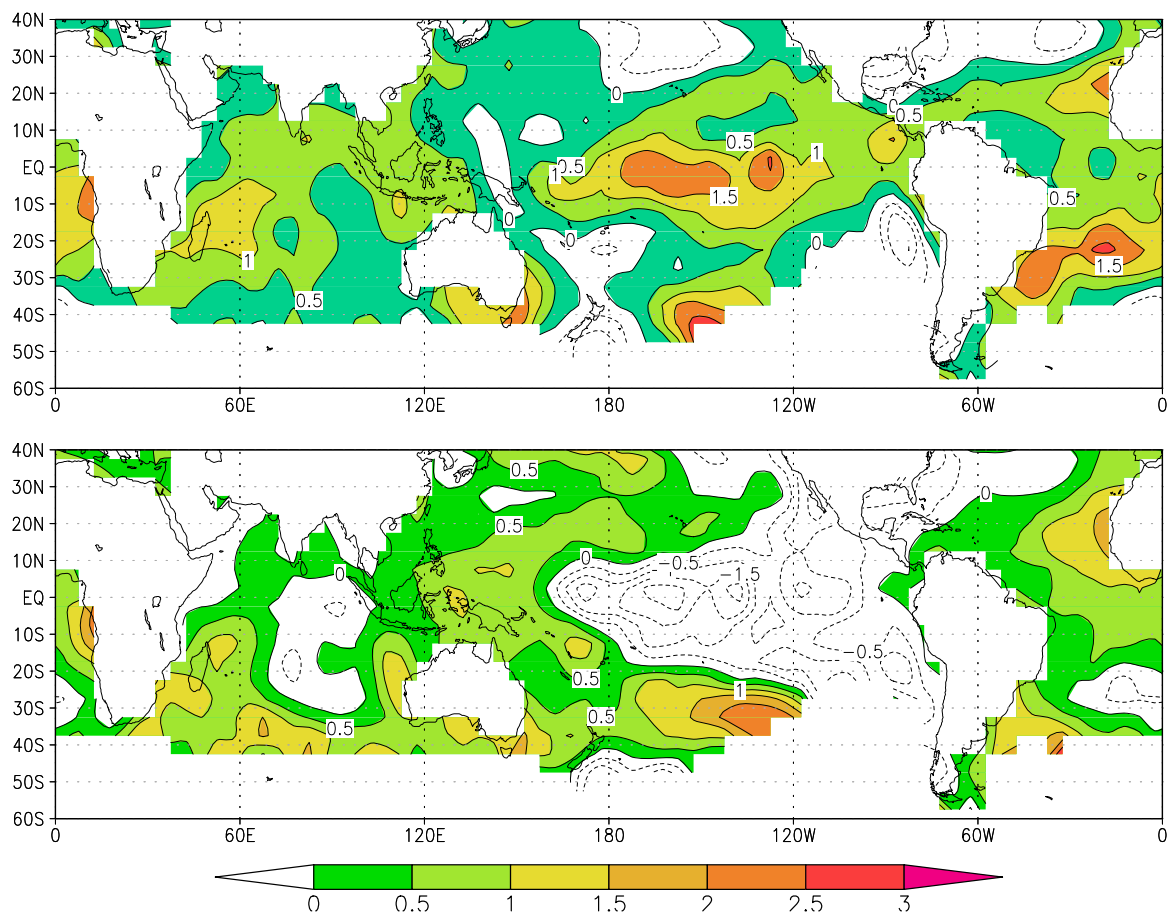

Figure 2 - Sea surface Temperature (SST, C) anomaly for January of 2010 (top) and 2011 (down).
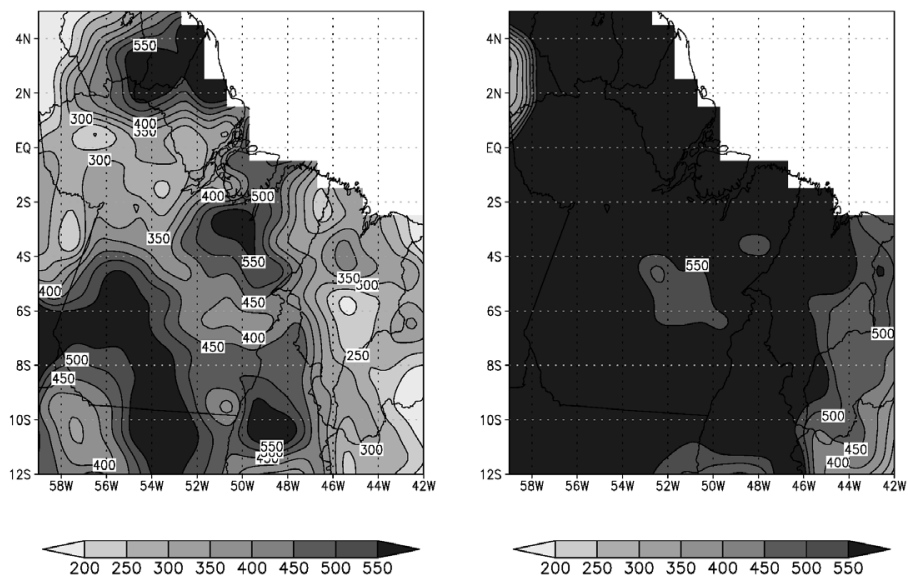

Figure 3 - Continental accumulated precipitation based on raingauges as provided by the GPCP for January-February of 2010 (left) and 2011 (right).

Applications (MERRA, Rienecher et al., 2011). Finally, the model results were analyzed to check if OLAM was able to forecast possible dry or wet regimes for the eastern Amazon.

\section{RESULTS AND DISCUSSION}

\subsection{Model evaluation for precipitation, temperature and winds}

A series of model evaluation were conducted to examine its performance. The results of accumulated precipitation for
January 2010 are presented at the Figure 4 . The results show that OLAM is able to represent the major precipitation regions over the Americas and surroundings. The model represents well the major rainfall accumulation over the North and South Atlantic, over the continental South America, and the precipitation associated with the ITCZ. Some global models show erroneous double-ITCZ at the eastern Pacific near the South America (Hwang and Frierson, 2013), but OLAM simulates a correct ITCZ position over this area. OLAM simulated well not only the spatial distribution, but also the precipitation amount. The domain averaged precipitation simulated by the model $(79.7 \mathrm{~mm})$ 

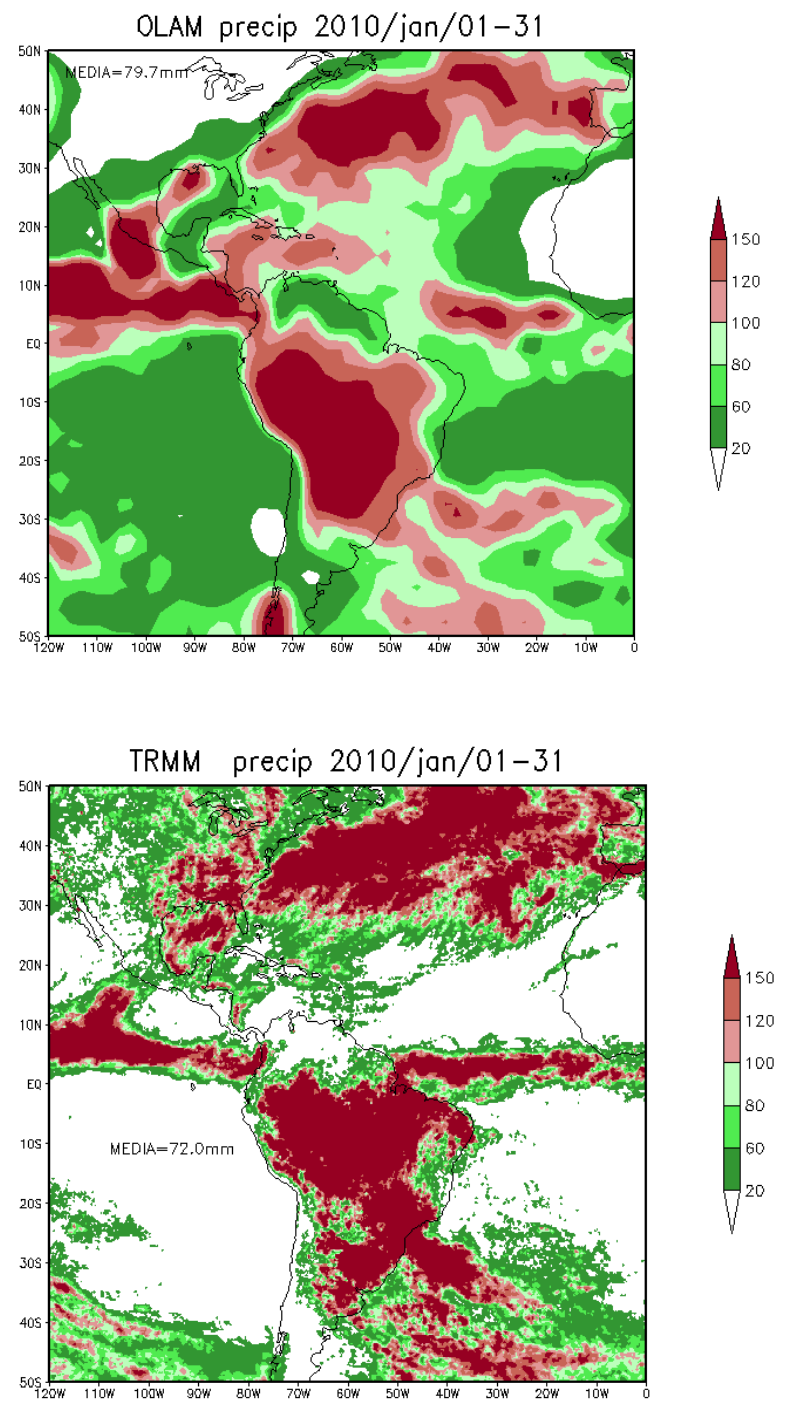

Figure 4 - Accumulated precipitation for January 2010 as obtained from the OLAM model (top) and estimated by the TRMM satellite (bottom).

was in great accordance with the TRMM estimates $(72.0 \mathrm{~mm})$.

Analysis of the near surface temperature at a center domain grid point shows that the model is able to represent correctly the daily cycle (Figure 5). Model results for this location shows that temperatures were between $21.0^{\circ} \mathrm{C}$ and $36.0{ }^{\circ} \mathrm{C}$ for the year of 2010 and between $21.0{ }^{\circ} \mathrm{C}$ and 34.0 ${ }^{\circ} \mathrm{C}$ for the year of 2011 . The results show that the dry year of 2010 had higher maximum temperatures as compared with 2011. A comparison with the NCEP data show that in some cases the simulated temperatures were warmer than the observations. The reasonable results for the near surface temperature show that the energy balance is maintained during the model integration.
A comparison between the simulated winds and the NCEP/NCAR data for a center domain grid point shows that OLAM represents well the dynamics of the region (Figure 6). The zonal wind at the center domain is predominantly from east. The simulated zonal wind for 2011 is slightly stronger than the observations. The meridional winds are very well simulated by the model as compared with the observations.

Spatial correlation coefficients and bias between OLAM and observations for monthly accumulated precipitation, air temperature (at 2 meters), and wind components (at 10 meters) were estimated and are presented at Table 1. The monthly precipitation was compared with maps of observations from two sources: GPCP and TRMM data. The air temperature and winds were compared with monthly mean data from MERRA reanalysis data. The coefficients show that temperature and winds have a higher spatial correlation than precipitation. Indeed, precipitation at this region is mainly produced by convective storms and representing their proper location is not possible due to their highly nonlinear nature. Furthermore, the model shows low bias for winds and a negative bias for temperature and precipitation accumulation. Other recent regional modeling studies for this region shows similar precipitation bias (Chou et al., 2005; Souza et al., 2009). It is likely that these regionals models still don't have enough spatial resolution to resolve the local sea-breeze circulation and the associated convective clouds that form at this interface with the ocean.

\subsection{Regional climate estimates}

The model performance to forecast the characteristic of the rainy season was obtained through a comparison between the two simulations (i.e. 2010 and 2011). Figure 7 shows the model results for accumulated precipitation for January-February of 2010 and 2011, respectively. The results show that accumulated precipitation is higher for the early 2011 as compared with the same period of 2010. On the average, in 2011 the accumulation was about $43 \%$ higher than for 2010 . These results show good agreement with the observed precipitation regimes (Figure 3). Therefore if the global SST fields are correctly updated, OLAM is able to estimate if the coming rainy season would be dry or wet.

A further run for 90 days was conducted to evaluate the model performance on this longer period of predictability. Again, the results show that OLAM was able to correctly infer that the rainy season of 2011 would have higher precipitation, as compared with the period of 2010 (Figure 8).

\section{CONCLUSIONS}

Numerical modeling runs were obtained with OLAM model to evaluate its performance to forecast if a rainy season 

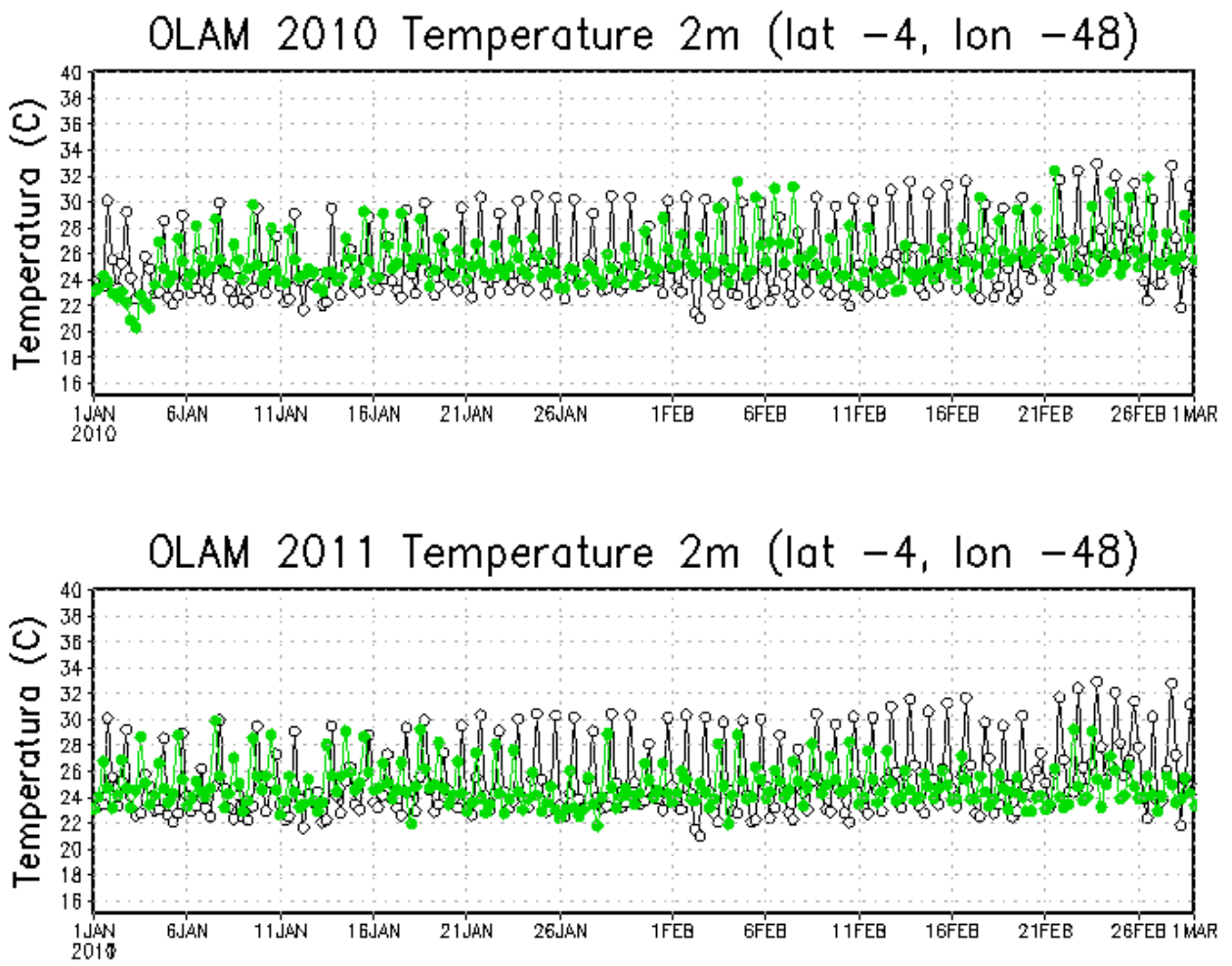

Figure 5 - Temperature at 2 meters at the center of the innermost domain (latitude $04 \mathrm{~S}$; longitude 48W) as obtained from the OLAM model (black line) and NCEP data (green line) for 2010 (top) and 2011 (bottom).

Table 1 - Domain spatial correlation coefficients and bias between OLAM and observations for: monthly mean accumulated precipitation (GPCP and TRMM data), air temperature at $2 \mathrm{~m}(\mathrm{~T} 2 \mathrm{~m})$, and zonal $(\mathrm{u} 10 \mathrm{~m})$ and meridional $(\mathrm{v} 10 \mathrm{~m})$ winds at $10 \mathrm{~m}$.

\begin{tabular}{|l|l|l|l|l|l|l|}
\hline & & \multicolumn{2}{|l|}{ Precipitation } & T2m & U10m & V10m \\
\cline { 3 - 5 } & & GPCP & TRMM & & & \\
\hline Correlation & January 2010 & 0.47 & 0.55 & 0.57 & 0.87 & 0.70 \\
\hline & February 2010 & 0.49 & 0.41 & 0.43 & 0.83 & 0.51 \\
\hline & January 2011 & 0.47 & 0.26 & 0.72 & 0.91 & 0.41 \\
\hline & February 2011 & 0.48 & 0.01 & 0.73 & 0.93 & 0.82 \\
\hline Bias & January 2010 & -106 & -97 & -0.5 & 0.0 & 0.0 \\
\hline & February 2010 & -86 & -102 & -0.9 & 0.1 & 0.2 \\
\hline & January 2011 & -164 & -171 & -0.6 & -0.1 & 0.1 \\
\hline & February 2011 & -147 & -205 & -1.0 & -0.2 & -0.1 \\
\hline
\end{tabular}

would be wet or dry. The major conclusion from the results based on the comparison between the rainy regimes of the years 2010 and 2011 shows that OLAM is able to infer with at least 03 months in advance the regional climate. However this modeling performance assumes that good initial conditions are correctly provided.

The SSTs used here was based on observations and therefore a good oceanic prediction is also required. At this moment OLAM does not have an oceanic predicting system. We are now implementing an oceanic coupling based on the HYbrid Coordinate Ocean Model (HYCOM, Chassignet et al., 2009).

The results obtained here used only two differing regional climate regimes (i.e. 2010 and 2011).However, more tests for other years would be required.. This task is an ongoing project and will be provided on further studies.

One major advantage of OLAM is that it allows a twoway interaction between the regional climate and the large scale systems. The relevant results obtained shows that OLAM can be 

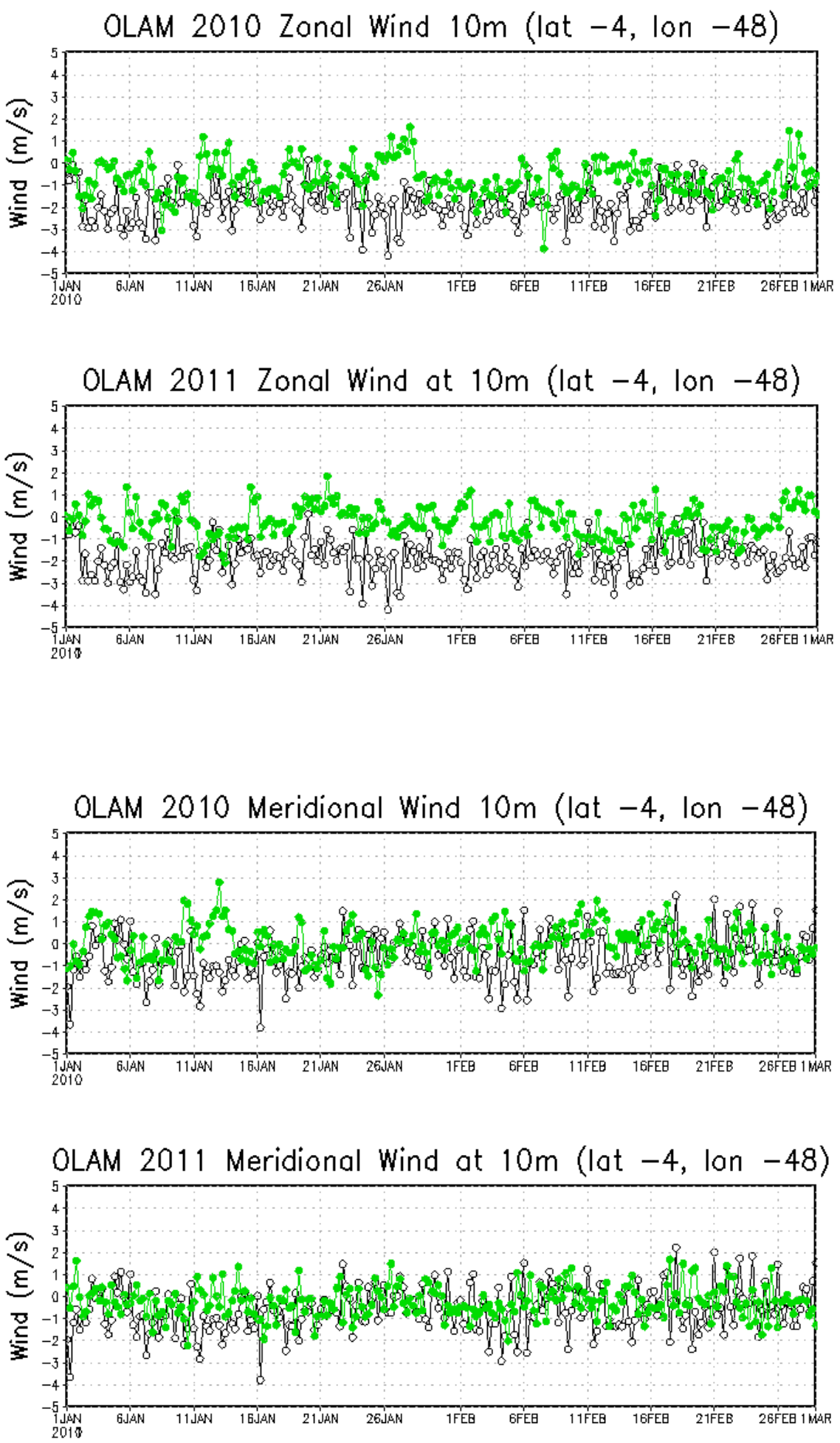

Figure 6 - Winds at 10 meters at the center of the innermost domain (latitude $04 \mathrm{~S}$; longitude $48 \mathrm{~W}$ ) as obtained from the OLAM model (black line) and NCEP data (green line) for 2010 and 2011. 

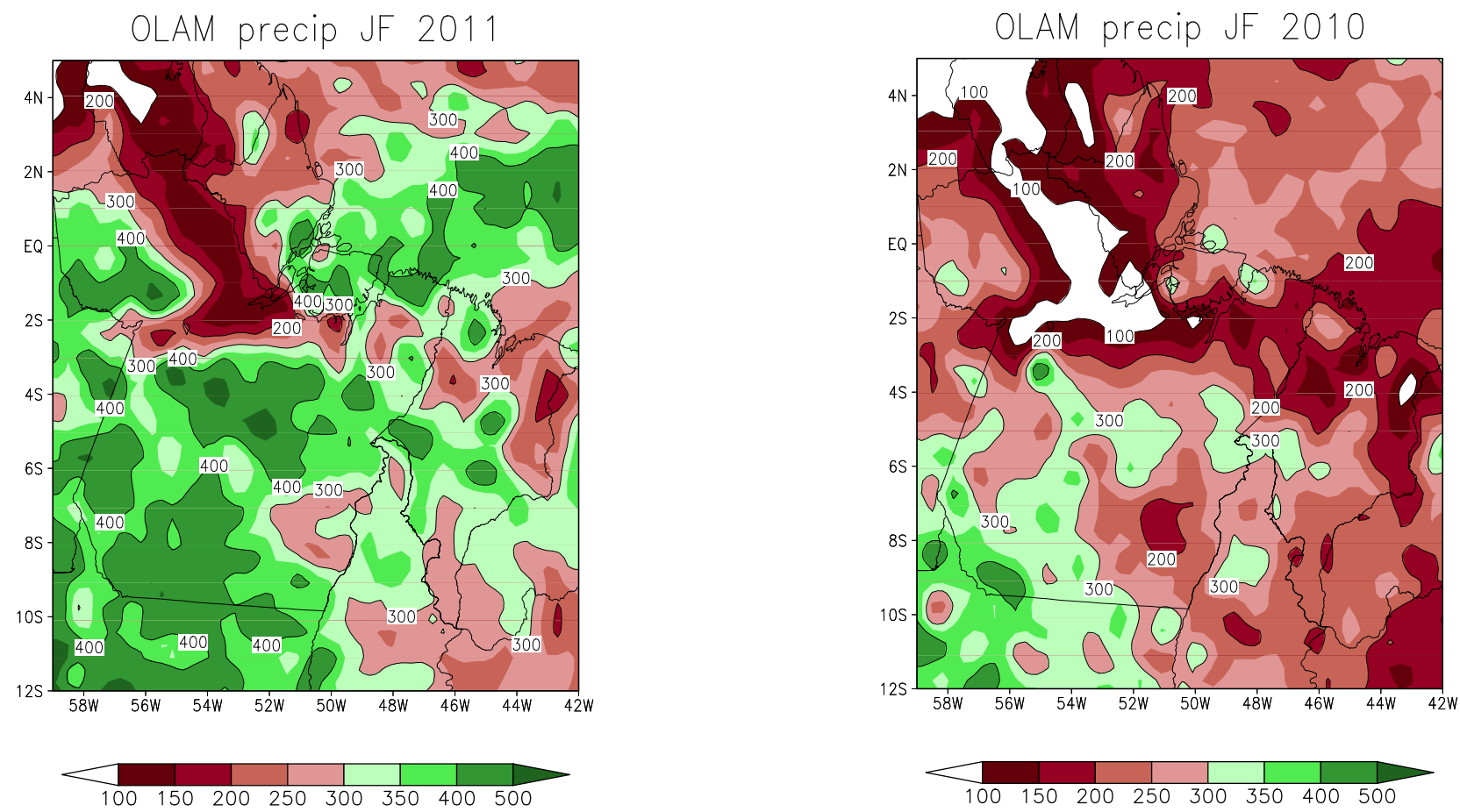

Figure 7 - Accumulated precipitation (mm) for January-February for 2010 (left) and 2011 (right).

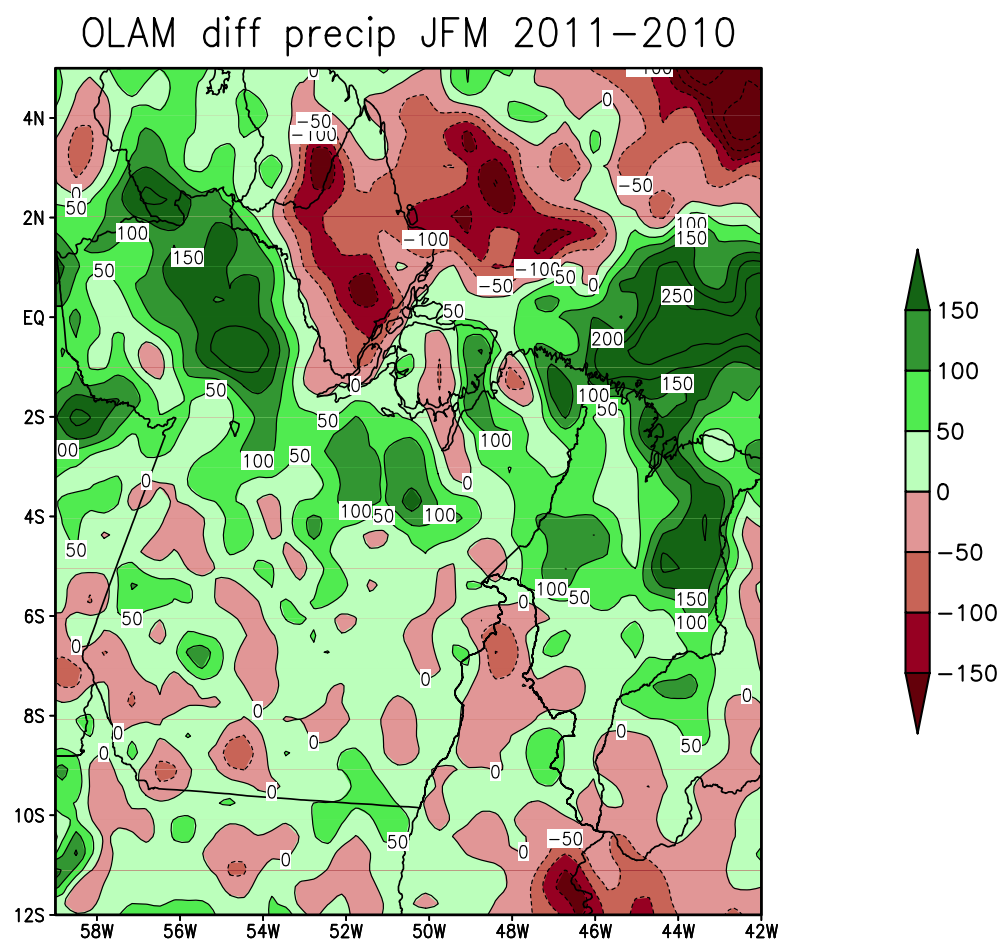

Figure 8 - Precipitation difference $(\mathrm{mm})$ between 2011 and 2010 for the three months simulation including January to March. 
an important tool for regional climate estimates for the eastern Amazon and other regions.

\section{ACKNOWLEDGMENTS}

The authors thanks to "Ministério de Ciência e Tecnologia" (MCT) and to "Financiadora de Estudos e Projetos" (FINEP), for the support to REMAM Project, and for Conselho Nacional de Desenvolvimento Científico e Tecnológico (CNPq) for grants support.

\section{BIBLIOGRAPHIC REFERENCES}

ALVES, J. M. B.; DE SOUZA, E. B.; COSTA, A. A . Sobre o sinal de um downscaling dinâmico às oscilações intrasazonais de precipitação no setor norte do Nordeste do Brasil. Revista Brasileira de Meteorologia, v. 27, p. 219-228, 2012.

CHASSIGNET, E. P. et al. . U.S. GODAE: Global Ocean Prediction with the HYbrid Coordinate Ocean Model (HYCOM). Oceanography, v. 22, n. 2, 64-75, 2009.

CHEN, C.; COTTON, W. R. A One-dimensional Simulation of the Stratocumulus-capped Mixed Layer, Boundary-Layer Meteorology, v. 25, p. 289-321, 1983.

CHOU, S.C.; BUSTAMANTE, J.F.; GOMES, J.L. Evaluation of Eta Model seasonal precipitation forecasts over South America. Nonlinear Processes in Geophysics, v.12, p.537$555,2005$.

CLIMANÁliSE, Boletim de Monitoramento de Análise Climática. São Paulo: SCT/INPE-CPTEC, v. 25, n. 01, Janeiro de 2010.

CLIMANÁlisE, Boletim de Monitoramento de Análise Climática. São Paulo: SCT/INPE-CPTEC, v. 26, n. 01, Janeiro de 2011.

COHEN, J. C. P.; SIlvA DIAS. M. A. F; NOBRE, C. A.. Environmental conditions associated with Amazonian squall lines: a case study. Monthly Weather Review, v. 123, n. 11, p. 3163-3174, 1995.

COTTON W. R. et al. RAMS Current Status and future directions. Meteorology and Atmopheric Physics, v. 82, p. 5-29, 2003.

DA ROCHA, R. P. et al. Effects of RegCM3 parameterizations on simulated rainy season over South America. Climate Research, v. 52, p. 253-265, 2012.

FERREIRA, W. R. S. et al. Sazonalidade da precipitação para a Amazônia usando o modelo REGCM3: avaliando apenas a forçante do Atlântico Equatorial. Revista Brasileira de Meteorologia, v.27, n.4, 435 - 446, 2012.

FREITAS, E. D. et al. A simple photochemical module implemented in RAMS for tropospheric ozone concentration forecast in the metropolitan area of Sao Paulo, Brazil: Coupling and validation. Atmospheric Environment, v. 39, p. 6352-6361, 2005.

FREITAS, S. R. et al. Aconvective kinematic trajectory technique for low resolution atmospheric models. Journal of Geophysical. Research, v. 105, n. D19, p. 24,375-24,386, 2000.

GANDU, A. W.; COHEN, J. C. P.; SOUZA, J. R. S. . .Simulations of deforestation in Eastern Amazon using a higher-resolution model. Theoretical and Applied Climatology, v. 78, p. 123-135, 2004.

GONÇALVES, F. L. et al. Effect of bacterial ice nuclei on the frequency and intensity of lightning activity inferred by the BRAMS model, Atmospheric Chemistry and Physics, v. 12, p. 5677-5689, doi:10.5194/acp-12-5677-2012, 2012.

GRELL, G.A.; DÉVÉNYI D. A generalized approach to parameterizing convection combining ensemble and data assimilation techniques. Geophysical. Research Letters, v. 29, n. 14, p. 1693, doi:10.1029/2002GL015311, 2002.

GRIMM, A.M. The El Nino impact on the summer monsoon in Brazil: Regional processes versus remote influences. Journal of Climate, v. 16, p. 263-280, 2003.

HARRINGTON, J. Y.; OLSON P. Q. On the potential influence of ice nuclei on surface-forced marine stratocumulus cloud dynamics. Journal Geophysical Research, v. 106, p. 27473-27484, doi: 10.1029/2000JD000236, 2001.

HWANG, Y-T; FRIERSON, D. M. W. Link between the double-Intertropical Convergence Zone problem and cloud biases over the Southern Ocean, Proceedings of the National Academy of Sciences: 1213302110v1201213302, 2013.

KAIN, J. S.; FRITSCH J. M. A one-dimensional entraining/ detraining plume model and its application in convective parameterization. Journl of Atmospheric Sciences. v. 47, p. 2784-2802, 1990.

KANAMITSU et al. NCEP-DEO AMIP-II Reanalysis (R-2). Bulletin of the American Meteorological Society, v. 83, p. 1631-1643, 2002.

KILADIS G. N. et al. Convectively coupled equatorial waves, Reviews of Geophysics, DOI: 10.1029/2008RG000266, 2009.

LONGO, K. M. et al. The chemistry CATT BRAMS model (CCATT BRAMS 4.5): a regional atmospheric model system for integrated air quality and weather forecasting and research. Geoscientific Model Development Discussions, v. 6, p. 1173-1222, 2013.

MADDEN, R. A.; JULIAN, P. R. Description of global-scale circulation cells in the tropics with a 40-50 days period. Journal of the Atmospheric Sciences, v. 29, p.1109-1123, 1972. 
MARENGO, J. A. Interdecadal variability and trends of rainfall across the Amazon basin. Theoretical and Applied Climatology, v, 78, p. 79-96, 2004.

MEDVIGY D.; WALKO R.; AVISSAR R.. Effects of deforestation on spatiotemporal distributions of precipitation in South America, Journal of Climate, v. 24, p. 2147-2163, doi: 10.1175/2010JCLI3882.1, 2011.

MEDVIGY D. WALKO R.; AVISSAR R. Modeling interannual variability of the Amazon hydroclimate, Geophysical Research Letters, v. 35, p. L15817, doi:10.1029/2008GL034941, 2008.

MEDVIGY, D.;WALKO R.; AVISSAR R. Simulated Links between Deforestation and Extreme Cold Events in South America. Journal of Climate, v. 25, p. 3851-3866. doi: http://dx.doi.org/10.1175/JCLI-D-11-00259.1, 2012.

MEYERS, M. P. et al. New RAMS cloud microphysics parameterization .2. The two-moment scheme. Atmospheric Research, v. 45, p. 3-39, 1997.

MOURA A. D.; SHUKLA J. On the dynamics of droughts in northeast Brazil: Observations, theory, and numerical experiments with a general circulation model. Journal of the Atmospheric Sciences, v. 38, p. 2653-2675, 1981.

NOBRE, P.;SHUKLA J. Variations of sea surface temperature, wind stress, and rainfall over the tropical Atlantic and South America. Journal of Climate, v. 9, p. 2464-2479, 1996.

RAMOS DA SILVA, R.; AVISSAR R.. The hydrometeorology of a deforested region of the Amazon. Journal of Hydrometeorology, v. 7, p. 1028-1042, 2006.

RAMOS DA SILVA, R. et al . Cloud streets and land water interactions in the Amazon. Biogeochemistry (Dordrecht), p. 1-11, 2011.

RAMOS DA SILVA, R. et al. Modelo OLAM - (Ocean Land Atmosphere Model) Descrição, Aplicações e Perspectivas, Revista Brasileira de Meteorologia, v. 24, n. 2, p. 144157, 2009.

RAMOS DA SILVA, R. et al. Progressos na Detecção e Previsão de Eventos Meteorológicos Extremos na Amazônia Oriental, Boletim da Sociedade Brasileira de Meteorologia, SBMET, 2007.

RAMOS DA SILVA, R.; WERTH D.; AVISSAR R. Regional Impacts of Future Land-Cover Changes on the Amazon Basin Wet-Season Climate. Journal of Climate, v. 21, n. 6, p. 1153-1170, 2008.

REYNOLDS, R.W. et al An improved in situ and satellite SST analysis for climate. Journal of Climate, v. 15, p. 16091625, 2002.

RIENECKER, M. M., et al, MERRA: NASA's ModernEra Retrospective Analysis for Research and Applications. Journal of Climate, v. 24, p. 3624-3648, doi:10.1175/JCLI-D-11-00015.1, 2011.
ROADS, J. et al., International Research Institute/Applied Research Centers (IRI/ARCs) regional model intercomparison over South America, Journal of Geophysical Research, v. 108, p. 4425, doi:10.1029/2002JD003201, D14, 2003.

ROBERTSON, A. W.; MECHOSO C. R.; KIM Y. J., The influence of Atlantic sea surface temperature anomalies on the North Atlantic Oscillation. Journal of Climate, v. 13, p. 122-138, 2000.

SILVA DIAS, M. A. F. et al. River breeze circulation in Eastern Amazon: observations and modeling results. Theoretical and Applied Climatology, v. 78, p. 111-121, 2004.

SOUZA E. B.; AMBRIZZI T. Modulation of the intraseasonal rainfall over tropical Brazil by the Madden Julian Oscillation. International Journal of Climatology, v. 26, n. 13, p. 1759-1776, 2006.

SOUZA, E. B. et al . Precipitação sazonal sobre a Amazônia oriental no período chuvoso: observações e simulações regionais com o RegCM3. Revista Brasileira de Meteorologia, v. 24, n. 2, p. 111-124, 2009.

UVO C. B. et al., The relationships between tropical Pacific and Atlantic SST and Northeast Brazil monthly precipitation. Journal of Climate, v. 11, p. 551-562, 1998.

WALKO, R. L.; AVISSAR R. The Ocean-Land-Atmosphere Model (OLAM). Part I: Shallow-water testes. Monthly Weather Review, v. 136, p. 4033-4044, 2008a.

WALKO, R. L.; AVISSAR R. The Ocean-Land-Atmosphere Model (OLAM). Part II: Formulation and Tests of the NonHydrostatic Dynamic Core, Monthly Weather Review, v. 136, p. 4045-4062, 2008b.

WALKO, R. L. et al. Coupled atmosphere-biophysics-hydrology models for environmental modeling. Journal of Applied. Meteorology, v. 39, p. 931-944, 2000a.

WALKO, R.L. et al. Efficient computation of vapor and heat diffusion between hydrometeors in a numerical model. Atmospheric. Research, v.53, p.171-183, 2000b.

WALKO, R. L. et al. New RAMS cloud microphysics parameterization .1. The single-moment scheme. Atmospheric Research, v. 38, p. 29-62, 1995.

WANG, H.; FU R. The Influence of Amazon Rainfall on the Atlantic ITCZ through Convectively Coupled Kelvin Waves. Journal of Climate, v. 20, p. 1188-1201, doi: http://dx.doi. org/10.1175/JCLI4061.1, 2007.

WERTH, D.;AVISSAR R., The local and global effects of Amazon deforestation, Journal of the Geophysical Research, v. 107, p. 8087, doi:10.1029/2001JD000717, 2002. 